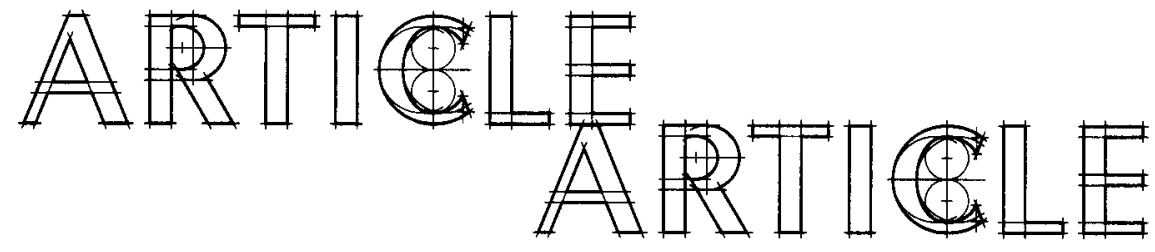

\title{
Competency Corner, Part Three: Practice-based Weightings of the CBPS
}

\section{Coin des compétences, troisième partie : Les pondérations fondées sur la pratique des NRFC}

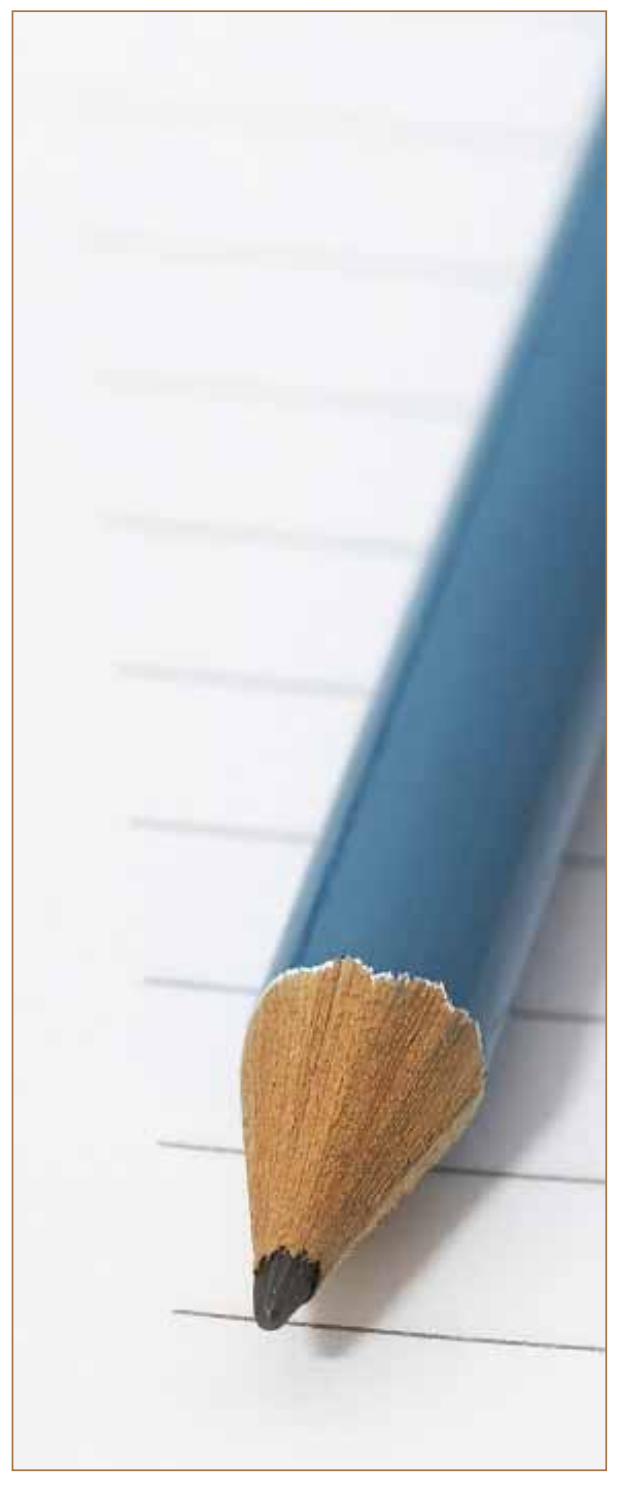

\section{Abstract}

The frst two artides in this series outlined the task, research, terminology and processes the Competence Committee used to develop the Competency-based Performance Standards (CBPS). These standards were designed as a framework for revision of the $\mathrm{C}$ anadian Standard A ssessment in 0 ptometry (C SA 0 ) to directly link the ex am and practioe requirements of $\mathrm{C}$ anadian 0 ptometrists. This linkage required determination of the relative weight to be assigned to each of the various competencies. W ork ing groups of practising optometrists rated the frequency and criticality of performanoe of each of the competencies using a standardized rating system. Results indicated that the majority of a revised CSA 0 would foous on providing comprehensive eye and vision care ( $78 \%)$, followed by management $(11 \%)$ and collaboration $(10 \%)$. The ratings also allowed calculation of the appropriate weighting of the underlying general attributes. The heaviest weighting was assigned to candidates' professional optometric knowledge and the ability to apply this knowledge (41\%), followed by communication (27\%), planning (13\%), ethics $(11 \%)$ and self-directed learning ( $8 \%)$. The last artide in this series will describe work to evaluate the ompetenoe based weightings of the current CSA 0 and to describe plans for future versions of the CSA 0 .

\section{Résumé:}

L es deux premiers articles dans cette série faisait état du mandat du Comité des compétenos, ainsi que des travaux, de la terminologie et des processus dont il s'est
For the Competence Committee of the Canadian Examiners in Optometry (2005-2006): T. Winslade (Chair, Competence Committee) N. Winslade (External Consultant, Competence Committee), R. Chou,

B. Cyr, B. Hawkins.

June 2007

This article of Competency Corner is Part Three of a Four Part series. 
inspiré pour établir les normes de rendement fondées sur les compé tences (N RFC). Ces normes doivent servir de cadre à la révision de l'É valuation canadienne standardisée en optométrie (É CSO) afn d'établir un lien direct entre les ex igenœes de l'ex amen et de la pratique pour les optométristes au C anada. À cette fn, il faut dé terminer le poids relatif à attribuer à chacune des compétences. $D$ es groupes de travail d'optométristes en ex erciœ ont évaluéla fréquence et l'importanœ du rendement pour chacune des compétenoes selon un système de notation normalisé. L es résultats indiquent que la plus grande partie d'une É C SO révisée porterait sur la prestation de soins des yeux et de la vue (78\%), et ensuite sur la gestion (11\%) et sur la collaboration (10 \%). L a notation nous a aussi permis de calculer la pondération à attribuer aux caractéristiques générales fondamentales. L a pondération la plus élevée a été attribuée à la connaissance professionnelle de l'optométrie chez les candidats et à leur capacité de mettre en pratique cette connaissance (41\%), ensuite à la communication (27\%), à la planifration (13\%), à la déontologie (11\%) et à l'autoapprentissage (8\%). L e dernier article dans œette série décrira le travail d'évaluation des pondérations fondées sur les compétences de l'É CSO actuelle et présentera les projets en vue d'autres versions de l'É C SO.

\section{INTRODUCTION}

The previous two articles outlined the task, research, terminology and processes the Competence Committee used to develop the Competency-based Performance Standards (CBPS). The CBPS describes the competencies required of optometrists to provide safe and effective care in Canada. In the first article we discussed the Canadian Standard Assessment in O ptometry (CSAO), which assesses the competence of candidates at entry to practice. The Competence Committee was charged with describing competence in a clear and concise manner so that questions on the CSAO could be plainly linked to the daily activities of practising optometrists. The second article details how the CBPS were developed in conjunction with grass roots optometrists and stakeholders, and that the CBPS describe the activities that competent optometrists should be able to perform on a routine basis. To be useful as the basis of the CSAO, however, the Competence Committee had to determine the relative importance or weight that should be assigned to each of the various competency units, elements and performance criteria. A list of the content or competencies to be assessed, along with the number of items or percent of the assessment assigned to each of these content areas or competencies, is referred to as the blueprint for the assessment. Thus, "a test blueprint is a tool used in the process of generating content-valid exams by linking the subject matter and the items appearing on the test" ${ }^{\text {. }}$ The committee was faced with determining the best approach to make these weighting decisions and again the committee turned to the literature for guidance.

\section{FREQUENCY AND CRITICALITY}

The most relevant literature was that from Michael $\mathrm{K}$ ane, who had worked with nurses to define the relative importance of their various professional responsibilities for preparation of licensure examinations ${ }^{2,3}$. Adapted to optometry, the principles of Kane's work required optometrists to determine for each competency:

(1) How often optometrists perform the task? That is, what is the frequency of the task?

(2) How critical is it to the welfare of the patient that optometrists perform the task correctly? That is, what is the criticality of the task?

A series of working group meetings were scheduled beginning with a pilot session in Montreal, followed by sessions in Halifax, $\mathrm{O}$ ttawa and Calgary. As with the development of the CBPS, grass roots optometrists formed the majority of these working groups and were selected to ensure an appropriate representation of all categories of optometrists. In total, more than 35 optometrists participated in the ranking of the CBPS (Appendix 1). This number and range of optometrists allowed each participant to consider only his/ her practice, thereby making it easier to make the ratings practical and realistic. Each optometrist did not have to imagine other people's practice but could focus on what (s)he did on a daily basis.

The Competence Committee developed specific rating scales to reflect the workflow of optometrists. The initial rating scales were based on literature recommendations ${ }^{3}$

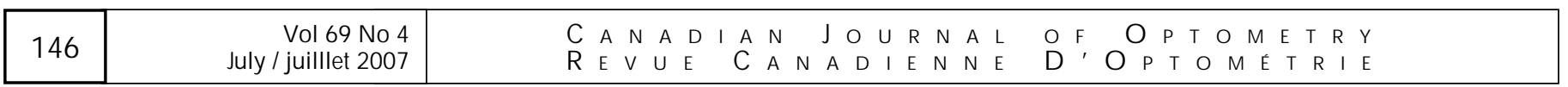




\section{ARTICLE ARTICLE}

and similar work by other health professions' assessment committees such as the Pharmacy Examining Board of Canada ${ }^{4}$. These scales and processes were trialed at the pilot working group meeting in Montreal. The final rating scales are provided in Appendix 2. For frequency ratings, workshop participants were asked to individually rate each performance criterion considering how often (s)he actually performed the activity in his/ her daily, typical practice. Participants were not to consider how often they thought about performing the activity (i.e. assessing whether it is necessary to perform the activity or not), but how often they actually performed the activity.

When rating criticality, participants were asked to consider how serious the consequences would be for patients should the task not be performed or not be performed correctly. Consideration of such risk to patients is important to ensure that the CSAO assesses candidates on their competence to perform tasks that, although infrequent in practice, carry substantial risk to patients.

Recalling that the CBPS describe four major tasks required of optometrists and are structured according to Figure 1, workshop participants were asked to rate the frequency and criticality for each performance criterion rather than rating at either the unit or element level. This process was specifically designed to facilitate the ranking since it was easier to focus on the discrete task described in an individual performance criterion. Competency elements and units are too broad and encompass too many activities, resulting in generally

\section{COMPETENCY UNITS}

Competency elements

$\longrightarrow$ Performance Criteria (mandatory)

Performance Indicators (examples)

Figure 1: Structure of CBPS high ratings for both frequency and criticality. Such results were not useful to discriminate among the competencies: therefore focus was maintained on the level of the performance criteria.

\section{INTEGRATING THE GENERAL ATTRIBUTES}

The final task of the working group participants was to determine the weighting of each of the general attributes underlying performance of the professional competencies. As outlined in earlier articles, the five general attributes (knowledge and reasoning skills, planning, communication, values and ethical principles, and self-directed learning), were identified by the Competence Committee as being critically linked to the professional competencies. The general attributes, therefore, are an integral part of the CBPS. The importance of these general attributes to practice should be reflected in the CSAO by stating the relative weight each general attribute receives in the assessment. To do this required that the working groups confirm the one or two general attributes that are most closely linked to each performance criterion. This allowed the calculation of the relative weighting of each general attribute within the overall CSAO.

\section{PRACTICE-BASED WEIGHTING OF THE CBPS}

The Canadian Examiners in Optometry's psychometrician, Dr. Anthony Marini, analyzed results of the working groups' ratings. Following principles outlined by Kane, the frequency and criticality ratings were combined to calculate an overall importanœ weighting for each performance criterion. Subsequent calculations allowed determination of the overall percentages of the exam that should, as based on actual daily practice of Canadian Optometrists, assess each competency element and unit. Figure 2 provides the percentages of a practice-based CSAO that would be assigned to assess each of the four professional competencies. As expected, the majority of the CSAO would focus on assessing the provision of comprehensive eye and vision care, followed by two additional competencies related to collaboration and management. Education of optometry 


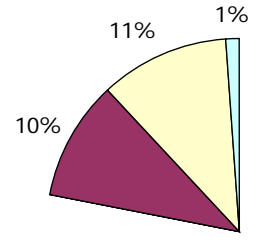

$78 \%$

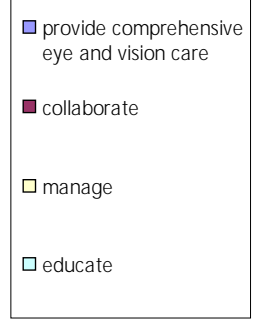

Figure 2. Percent weighting of the professional competencies on a practice-based CSAO

students, although important in principle, was assigned a minimal weighting within a practice-based CSAO .

Since the working groups also identified the one or more major general attributes linked to each performance criterion, calculations could also be completed to state the relative weighting of the general attributes embedded within a practice-based CSAO. As expected, the heaviest weighting was assigned to candidates' professional optometric knowledge and the ability to apply this knowledge (Figure 3); communication skills were weighted next highest, followed by planning, ethics and self-directed learning abilities.

\section{TWO DIMENSIONAL WEIGHTING}

The process developed of calculating a weighting for both the professional competencies and underlying general attributes within a practice-based CSAO represents a new approach to assessing critical areas such as communication, ethics and self-directed learning. Many assessment groups are working on methods of emphasizing the importance of such attributes. O ptometry's process of embedding these attributes within the assessment of the professional competencies offers an innovative approach that has not, to our knowledge, previously been reported in the literature.

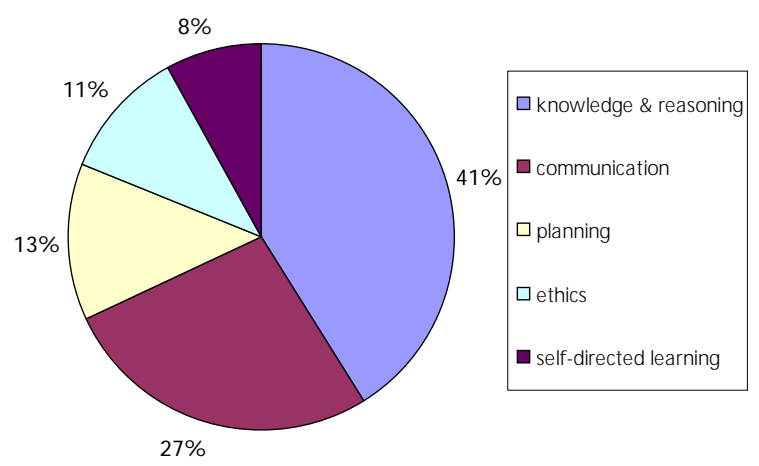

Figure 3. Percent weighting of the underlying general attributes on a practice-based CSAO

\section{SUM MARY:}

The Competence Committee's work to describe competence for Canadian O ptometrists and to develop a blueprint for a practice-based CSAO has been described. A process of assessing general attributes within the performance of professional competencies has been developed and practice-based weightings for these attributes reported. O ur last article in this series will describe work to evaluate the competence-based weightings of the current CSAO and to describe plans for future versions of the CSAO.

\section{ENDNOTES}

1. Bridge, PD, Musial, J, Frank, R. et al. (2003). Measurement practices: methods for developing content-valid student examinations. Medical Teacher, 25 (4), 414-421.

2. Kane, M., Kingsbury, C., Colton, D., Estes, C. (1989). Combining $\mathrm{D}$ ata on Criticality and Frequency in developing test plans for licensure and certification examinations. Journal of Educational Measurement, 26, 17-27.

3. Kane, M., Kingsbury, C., Colton, D., Estes, C. (1986). A study of Nursing Practice and role D elineation and Job Analysis of Entry-level Performance of Registered Nurses. American College Testing Program for the National council of State Boards of Nursing, Inc.: Chicago.

4. The Pharmacy Examining Board of Canada (1999) The Pharmacy Competency Review Survey: A national survey of entry-level pharmacy practice in Canada. 


\section{ARTICLE \\ ARTICLE}

\section{Appendix 1.}

Workshop Participants

\begin{tabular}{|c|c|c|c|}
\hline $\begin{array}{l}\text { Montreal - June } 2005 \\
\text { (Pilot) } \\
\text { Joyce Barbour } \\
\text { Howard Backman } \\
\text { Bernard Cyr } \\
\text { Gaeten Lang } \\
\text { Martin McD owell }\end{array}$ & $\begin{array}{l}\text { Halifax- December, } 2005 \\
\text { Michael Baird } \\
\text { Alan Baldock } \\
\text { Charlotte Bourgeois-Boudreau } \\
\text { Jeff Buchanan-D orrance } \\
\text { Alphonse Carew } \\
\text { Mark Chute } \\
\text { Rheal Comeau } \\
\text { Ed Grimm } \\
\text { Bruce Hawkins } \\
\text { Yves Levesque } \\
\text { Reid MacD uff } \\
\text { Janet Ray } \\
\text { Jacqui Smith }\end{array}$ & $\begin{array}{l}\text { Ottawa - January } 2006 \\
\text { Steven Bacher } \\
\text { Pierre Bessette } \\
\text { Harold Bergman } \\
\text { Julie Brule } \\
\text { Ralph Chou } \\
\text { William Clarke } \\
\text { Joseph Mittleman } \\
\text { Kirsten North } \\
\text { Denise Roy } \\
\text { Jim Tripp }\end{array}$ & $\begin{array}{l}\text { Calgary - April } 2006 \\
\text { Sallie Barclay } \\
\text { D avid Blaine } \\
\text { Robert D eMara } \\
\text { G eorge Fung } \\
\text { Thomas Lampard } \\
\text { Anthony Marini } \\
\text { (external consultant) } \\
\text { Anne Lorraine Oliver } \\
\text { Murray O shanyk } \\
\text { Mona Purba } \\
\text { Patricia Ross }\end{array}$ \\
\hline
\end{tabular}

\section{Appendix 2.}

Scales used by Competence Committee Working Groups to Rate the Frequency and Criticality of Performance of Professional Competencies.

\section{Frequency Rating}

In your practice, how frequently do you perform each of the listed tasks?

$6 \ldots \ldots$...Seven or more times per day (i.e. hourly or more)

5 ....... Between two and six times per day (but not hourly)

$4 \ldots \ldots .0$ nœ per day (i.e. five times per week)

$3 \ldots . .$. B etween one and four times per week (but not daily)

$2 \ldots \ldots$. Between one and three times per month (but not week ly)

$1 \ldots \ldots$...L ess than once per month

\section{Criticality Rating}

Considering each time that the competency unit should be performed, what risk would it cause the patient if the optometrist did not perform the competency, or performed it incorrectly?

$6 \ldots \ldots$ vision or life threatening

$5 \ldots \ldots$ serious onsequences

$4 \ldots \ldots$ worsens situation

$3 \ldots \ldots$ prevents improvement in situation

$2 \ldots \ldots$ causes inconvenience

$1 \ldots$... no impact 